\title{
Słupski ośrodek przemysłowy z perspektywy 25 lat transformacji gospodarczej
}

Transformacja systemu ekonomicznego kraju, której celem jest osiągnięcie warunków właściwych gospodarce rynkowej, wymagała restrukturyzacji wielu dziedzin życia społeczno-gospodarczego w Polsce. Ukształtowane bowiem w okresie powojennym układy gospodarcze, stosowne do ówczesnych potrzeb, koncepcji, możliwości i warunków zewnętrznych, w większości okazały się nieprzydatne w warunkach zmienionego otoczenia, innych potrzeb i priorytetów rozwojowych. Wymagały zatem restrukturyzacji, rozumianej jako proces przebudowy struktury. Podkreślić należy, że przemysł jest jednym z tych sektorów (obok rolnictwa uspołecznionego), w którym przestrzenne skutki transformacji zaznaczają się bardzo silnie. Jest to nie tylko związane ze zmianą wewnętrznych mechanizmów gospodarowania, lecz także z globalnymi procesami przemian (często określanymi mianem transformacji), coraz wyraźniej oddziałujących na strukturę i powiązania przestrzenne przemysłu w Polsce.

Dotychczasowe studia dotyczące transformacji obejmują najczęściej aspekty makroekonomiczne i ocenę zastosowanych strategii zmian (np. terapia szokowa). Z kolei na poziomie mikroekonomicznym większość badań empirycznych przedsiębiorstw pomija efekty restrukturyzacji (np. zmian strukturalnych, tendencji w zakresie przemian struktury gałęziowej i wielkościowej a przede wszystkim przemian w użytkowaniu i zagospodarowaniu terenów przemysłowych). Odczuwa się zatem potrzebę opracowań próbujących wniknąć głębiej w mechanizm zmian transformacyjnych, adaptacji do nowych warunków gospodarowania oraz kształtowania się nowych reakcji przestrzennych.

W świetle powyższych przesłanek celem opracowania jest zaprezentowanie zmian strukturalnych $\mathrm{w}$ działalności przemysłowej Słupska po 25 latach transformacji gospodarczej. Spośród licznych procesów zwią- 
zanych z terenami przemysłowymi zwrócono szczególną uwagę na zjawiska prowadzące do powstania tych terenów (ich źródła), niektóre cechy przekształceń oraz czynniki hamujące przekształcenia. Na marginesie pragnę zaznaczyć, że niniejszy artykuł nawiązuje tematycznie do wcześniejszych opracowań autora o funkcjach Koszalina i Słupska w regionalnej sieci osadniczej (Rydz 1990), roli i funkcji Słupska na tle sieci osadniczej środkowego Wybrzeża (Rydz, Zaleski 1992), procesów transformacji słupskiego ośrodka przemysłowego w latach 1990-1995 (Rydz, Jażewicz 1997), zmian w strukturze użytkowania ziemi na przykładzie Słupska i Szczecinka (Rydz 1999), efektów restrukturyzacji słupskiego ośrodka przemysłowego w okresie wdrażania gospodarki rynkowej (Rydz, Szymańska 2002) oraz przemian przestrzeni miejskiej Słupska w okresie urynkowienia gospodarki (Rydz 2009).

\section{Ogólna charakterystyka słupskiego ośrodka przemysłowego}

Już w XIX w. Słupsk stał się drugim po Szczecinie ośrodkiem przemysłowym na Pomorzu Zachodnim. Pewne ślady drobnej industrializacji

222 w Słupsku napotykamy już w okresie dekady lat 30. i 40. XIX stulecia, kiedy to uruchomiono 7 zakładów przemysłowych. $W$ tej wstępnej fazie uprzemysłowienia rozpoczęły produkcję m.in. 2 fabryki mebli, odlewnia żelaza i browar. W kolejnych latach uruchomiono m.in. fabrykę maszyn rolniczych z odlewnią żelaza, fabrykę elementów budowlanych (1874) i warsztaty naprawcze taboru kolejowego. W 1893 r. rozpoczęły produkcję dwie fabryki mebli, a w następnych latach trzy dalsze zakłady. Ogółem w przemyśle meblarskim w 1907 pracowało ponad 1000 osób (Lindmajer i in. 1986). W latach poprzedzających wybuch I wojny światowej potencjał przemysłowy Słupska wykrystalizował się zasadniczo wokół czterech wiodących branż. Był to przemysł drzewny - głównie meblarski, materiałów budowlanych, metalowo-maszynowy i spożywczy. Podkreślić należy, że ranga drugiego ośrodka produkcji pozarolniczej na Pomorzu Zachodnim nie zostałaby osiągnięta przez Słupsk, gdyby nie określony zespół sprzyjających czynników, zarówno obiektywnych, jak i subiektywnych - wynikających z protekcyjnej polityki ekonomicznej władz berlińskich wobec rolnictwa, zwłaszcza wielkoobszarowego, wschodnich prowincji ówczesnego państwa pruskiego. Do obiektywnych można zaliczyć obfitość określonych surowców, dzięki którym rozwinął się przede wszystkim przemysł drzewno-meblarski i materiałów budowlanych. Natomiast przemysł metalowo-maszynowy i pokrewne pracowały na zaopatrzenie rozległego zaplecza rolniczego, a ten w zamian oferował Słupskowi 
pod dostatkiem surowców stwarzających szansę rozwoju branży spożywczej (Machura 1975).

W okresie powojennych procesy industrializacji należały do głównych czynników przemian struktury przestrzennej kraju, prowadząc równocześnie do ukształtowania i specjalizacji terytorialnego podziału pracy (Rajman 2001). Działalność produkcyjna stała się głównym czynnikiem miastotwórczym i stymulatorem rozwoju gospodarczego wielu miast, w których wykształciły się chłonne rynki pracy, silnie powiązane z bliższym i dalszym zapleczem.

Istotną przeszkodą w rozwoju przemysłowym po wyzwoleniu były zniszczenia wojenne. Potencjał przemysłowy Słupska, uszczuplony $\mathrm{w}$ toku wojny (stopień zniszczeń wojennych wynosił około $60 \%$ ) oraz w wyniku demontażu na rzecz odszkodowań wojennych, stanowił bazę, którą trzeba było poddać zasadniczej rekonstrukcji i odbudowie. Odbudowa i uruchomienie przemysłu w Słupsku były zatem jednym z najbardziej skomplikowanych problemów, należało bowiem uwzględnić odmienne warunki kooperacji z innymi przemysłami, poważne zmiany w sytuacji szeregowej, wzgląd na strukturę przemysłu reszty kraju.

Wśród zagadnień lokalizacji przemysłu w przestrzeni Słupska istotną rolę odegrało środowisko geograficzne. Jego czynniki w zasadniczy sposób oddziaływały na lokalizację przemysłu. Największą rolę odegrały warunki budowlane i stosunki wodne. Niekorzystne na ogół warunki budowlane występują w Dolinie Słupi oraz częściowo na wschodnich stokach wysoczyzny. Barierę dla lokalizacji zakładów przemysłowych w kierunku wschodnim stanowiły z kolei obiekty i tereny wojskowe. Spowodowało to znaczne skupienie zakładów przemysłowych na terenie miasta (ryc. 1). Z prowadzonych badań wynika, że intensywny rozwój przemysłu w latach 1965-1980 zaowocował powstaniem silnie skoncentrowanych osiedli, położonych w zachodniej i południowo-zachodniej części miasta (osiedla: Piastów, Śródmieście i Nadrzecze). Zakłady zlokalizowane w tych trzech osiedlach zatrudniały prawie $89,0 \%$ pracujących $\mathrm{w}$ przemyśle miasta, a ich udział w produkcji globalnej przemysłu miasta wynosił 87,1\% (Rydz 1990). Stopień uprzemysłowienia pozostałych osiedli był znacznie mniejszy - wyjątek stanowiło osiedle Batorego ze względu na lokalizację tu Komunalnego Przedsiębiorstwa Naprawy Autobusów „Kapena”.

Jednym z ważniejszych elementów lokalizacji przemysłu w ośrodku słupskim był także układ komunikacyjny. Wzdłuż linii kolejowej ze Szczecina do Gdańska i z Piły do Słupska na osiedlu Nadrzecze i Piastów zlokalizowano największe zakłady przemysłowe, m.in. Słupskie Fabryki Mebli, Północne Zakłady Obuwnicze „Alka”, Słupską Fabrykę Maszyn Rolniczych i Fabrykę Cukrów „Pomorzanka” z dużymi powierzchniami magazynowymi. 


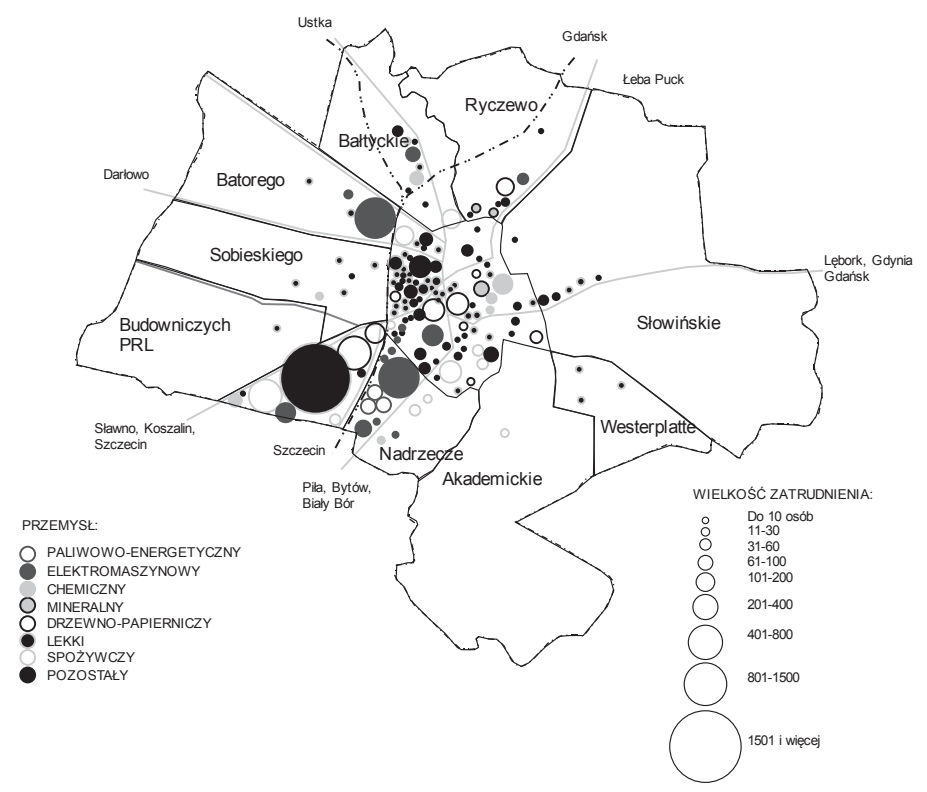

Ryc. 1. Rozmieszczenie zakładów przemysłowych według branży i wielkości zatrudnienia w Słupsku w 1990 r. Źródło: (Rydz 1990)

W okres nowego rozwoju społeczno-gospodarczego, charakteryzującego się m.in. powrotem do gospodarki rynkowej, Słupsk wkroczył z potencjałem przemysłowym zorganizowanym w 155 zakładach państwowych i spółdzielczych, w których w 1988 r. pracowało ponad 139 tys. osób (w 1980 r. w przemyśle pracowało około 15,5 tys.), czyli ponad 37\% czynnych zawodowo mieszkańców tego miasta i niemal 17\% ogółu osób, które tu mieszkały. Jest to dość wysoki wskaźnik zważywszy na fakt, że Słupsk był zawsze miastem o kilku wykształconych funkcjach, np. w zakresie szkolnictwa, ochrony zdrowia, administracji itd. Udział zatrudnionych w przemyśle Słupska, mimo że w latach 80 . ubiegłego wieku systematycznie malał, to i tak do 1990 r. stanowił główne źródło utrzymania i życiodajną funkcję miasta. Działalność produkcyjna nie tylko była głównym czynnikiem miastotwórczym, lecz także ukształtowała silne powiązania z bliższym i dalszym zapleczem poprzez codzienne dojazdy do zakładów przemysłowych - w 1983 r. liczba dojeżdżających do nich osób to 3093 osoby na ogólną liczbę 7801 dojeżdżających codziennie do Słupska (Rydz 1990).

Obserwowany w latach 1965-1980 wzrost zatrudnienia w przemyśle był głównie wynikiem budowy nowych zakładów. Przykładowo w 1960 r. na mocy uchwały Rady Ministrów zorganizowany został Słupski Ośrodek Meblarski, w skład którego weszły trzy przedsiębiorstwa zajmują- 
ce się produkcją mebli: Słupskie Fabryki Mebli (jako przedsiębiorstwo prowadzące), Słupskie Zakłady Przemysłu Terenowego oraz Spółdzielnia Pracy „Dąb Pomorski”. Także kolejne lata były kontynuacją pomyślnego rozwoju tego ośrodka. Dużym niekwestionowanym osiągnięciem tego okresu było przekazanie do eksploatacji trzech największych zakładów: Komunalnego Przedsiębiorstwa Naprawy Autobusów „Kapena” (1968), Północnych Zakładów Przemysłu Skórzanego „Alka” (1969) i Zakładów Sprzętu Okrętowego „Sezamor” (1970). Do największych przedsiębiorstw przemysłowych w Słupsku w połowie lat 80. ubiegłego wieku należałoby zatem: Północne Zakłady Przemysłu Skórzanego „Alka” (3600 zatrudnionych), Słupskie Fabryki Mebli (1750), Fabryka Maszyn Rolniczych „Famarol” (ok. 1100), Komunalne Przedsiębiorstwo Naprawy Autobusów „Kapena” (850) i Fabryka Cukierków „Pomorzanka” (650). Na terenie miasta koncentrowało się w roku 1988 około 41,9 zatrudnionych w przemyśle byłego województwa, zaś udział w produkcji globalnej przemysłu całego regionu wynosił ponad 62\% (Rydz 1990).

Innym wyznacznikiem roli przemysłu ośrodka słupskiego jest fakt, że wyprodukowano tu w 1989 r. około 3,5\% (1382 tys. par) ogólnokrajowej produkcji obuwia i około 8,2\% krajowej produkcji maszyn rolniczych, zaś udział w produkcji mebli w skali kraju wynosił około 2,2\%. Specyfiką przemysłu ośrodka słupskiego było w przeszłości wyraźne zróżnicowanie branżowe (Rydz, Zaleski 1992). Największy udział w potencjale przemysłowym miasta w 1988 r. miały: przemysł skórzany $(27,0 \%)$, spożywczy (156\%), drzewny (151\%) i środków transportu (13,6\%), jeśli za miernik przyjmiemy liczbę zatrudnionych (ryc. 2). Nieco inaczej kształtowała się struktura gałęziowa, gdy za miernik przyjmie się wartość produkcji globalnej. W 1989 r. największy był udział wartości produkcji przemysłu spożywczego (27,5\%), maszynowego (18,6\%), skórzanego $(15,1 \%)$, drzewnego $(14,6 \%)$ i środków transportu $(13,3 \%)$.

Godny uwagi jest fakt, że powierzchnia zajmowana przez zakłady przemysłowe najbardziej zindustrializowanego Słupska w strefie wybrzeża, pomiędzy aglomeracją gdańską i aglomeracją szczecińską, wynosiła 114,7 ha (dla porównania w Koszalinie tereny przemysłowe zajmowały 93,7 ha). Sześć największych pod względem zatrudnienia zakładów (Fabryka Maszyn Rolniczych, Północne Zakłady Obuwia, Słupskie Fabryki Mebli, Komunalne Przedsiębiorstwo Naprawy Autobusów, Fabryka Cukierków i Zakłady Urządzeń Okrętowych) zajmowały łączne 71,4 ha powierzchni zainwestowania przemysłowego. Pozostałe 149 zakładów, które prowadziły w 1983 r. działalność produkcyjna, zajmowały około 433 ha. $\mathrm{Z}$ porównania tych liczb wynika, że cechą przemysłu Słupska było dość znaczne rozdrobnienie potencjału produkcyjnego. Zakłady małe, zatrudniające mniej niż 50 pracowników, stanowiły blisko 75\% ogólnej liczby 
(Rydz, Zaleski 1992). Podkreślić należy, że w 1985 r. w 18 największych zakładach Słupska (zatrudniających ponad 200 osób) skupionych było 10065 osób, co stanowiło 72,6\% pracujących w przemyśle miasta.

\section{Zmiany strukturalne przemysłu ośrodka słupskiego}

W okresie transformacji polskiej gospodarki, szczególnie w pierwszym jej okresie, wystąpiły istotne różnice w zachowaniu podmiotów gospodarczych różnych sektorów i gałęzi. Miarami zamian strukturalnych są m.in. tempo przekształceń własnościowych, zmiany w liczbie i strukturze podmiotów gospodarczych oraz pozyskanie kapitału zagranicznego i jego „skłonności” do inwestowania. Dokonane analizy struktury własnościowej i organizacyjnej przedsiębiorstw przemysłowych Słupska wskazuja że do końca 2006 r. około 98\% zakładów uległo przekształceniom własnościowym. Pierwszym sprywatyzowanym przedsiębiorstwem był Browar Słupski, który wchodził w układ zespołu Koszalińskich Zakładów Piwowarskich. W następnych latach przekształceniom własnościowym poddane zostały wszystkie wiodące do niedawna zakłady przemysłowe Słupska, np. Północne Zakłady Przemysłu Skórzanego „Alka”, Słupskie 226 Zakłady Przemysłu Ziemniaczanego „Stolon”, Fabryka Cukierków „Pomorzanka", Słupska Fabryka Mebli. Najczęściej stosowaną formą prywatyzacji było przekształcenie w spółkę akcyjną skarbu Państwa lub w spółkę z ograniczoną odpowiedzialnością. Cztery przedsiębiorstwa ze Słupska o dość dobrej kondycji finansowej (Komunalne Przedsiębiorstwo Naprawy Autobusów „Kapena”, Zakłady Urządzeń Okrętowych „Sezamor”, Fabryka Maszyn Rolniczych "Agromet-Famarol” oraz Przedsiębiorstwo Zbożowo-Młynarskie) wytypowano do programu Powszechnej Prywatyzacji Narodowych Funduszy Inwestycyjnych (Rydz, Jażewicz 1997).

Przebieg procesów prywatyzacyjnych przemysłu w ośrodku słupskim zaznaczył się - obok wyraźnego spadku liczby pracujących (około 40\% w latach 1988-2005) - dość istotnymi zmianami struktury gałęziowej. W ukształtowanej zasadniczo w latach 70. strukturze przemysłu nastąpiły w okresie transformacji dość wyraźne zmiany: z jednej strony - wzrost znaczenia uruchomionej w latach 80. prywatnej firmy „Dom-Plast”, produkującej artykuły z tworzyw sztucznych, z drugiej zaś w kolejnych latach - znaczny rozwój tej firmy (m.in. w wyniku wykupienia całości udziałów przez koncern amerykański). Przebieg procesu restrukturyzacji gospodarki Słupska wskazuje również na wyraźny wzrost znaczenia w ogólnej strukturze przemysłu działu zajmującego się produkcją środków transportu. Jest to m.in. wynik uruchomienia w słupskiej „Kapenie” montowni ciągników siodełkowych i autobusów miejskich oraz utworzenia spółki 
Scania-Kapena z udziałem kapitału zagranicznego. W ostatnich latach Scania-Kapena należała do liderów w skali kraju w zakresie produkcji autobusów. Przykładowo w połowie 2008 r. ze Słupska eksportowano, m.in. do Skandynawii, Włoch, Anglii, 210 autobusów. Wśród nich były także pojazdy piętrowe, które Scania produkuje jako jedyna w Polsce. Suma wyników obu zakładów świadczy o tym, że w pierwszej połowie roku 2008 co trzeci nowy autobus sprzedawany w Polsce albo został wyprodukowany w Słupsku, albo przeszedł przez słupską sieć sprzedaży.
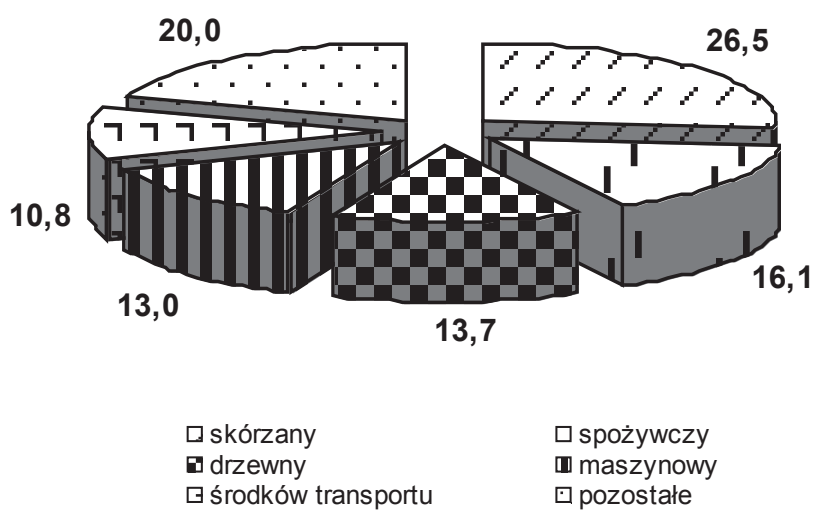

Ryc. 2. Struktura gałęziowa przemysłu Słupska według zatrudnienia w 1988 r. Źródło: (Rydz 1990)

Miarą przekształceń, jakie zaszły w ostatnim ćwierćwieczu w przemyśle Słupska jest dość istotne zmniejszenie roli tradycyjnych do niedawna w gospodarce miasta gałęzi przemysłu, m.in. przemysłu drzewnego, skórzanego i spożywczego. Zjawisko to zostało spowodowane wyraźnym ograniczeniem zatrudnienia w Fabryce Obuwia „Alka” z 1249 osób w 1994 r. do 341 osób na koniec 2002 r., a w dalszej kolejności - likwidacją zakładu, podobnie jak Słupskich Fabryk Mebli (2002) i Zakładów Przemysłu Mięsnego (1997).

Jeszcze bardziej radykalne zmiany zaszły w strukturze wielkościowej zakładów przemysłowych. Preferowany w latach 70. wzrost stopnia koncentracji zatrudnienia $\mathrm{w}$ dwóch zakładach nie sprostał w pełni wymogom gospodarki rynkowej po 1989 r. Wyrazem tego był nie tylko ogólny spadek zatrudnionych w przemyśle Słupska, lecz także niższy stopień koncentracji pracujących w dużych zakładach.

Prezentacja Słupskiego Ośrodka Przemysłowego wymaga podkreślenia, że na jego oblicze przemysłowe znaczny wpływ miały również zakłady o mniejszym zatrudnieniu. Do takich należała m.in. Słupska Fabryka 
Obrabiarek SAFO, która powstała na bazie poniemieckiej fabryki drewnianych śmigieł samolotowych. Zakład w okresie powojennym wyspecjalizował się w produkcji obrabiarek, szlifierek i innych specjalistycznych maszyn i urządzeń do obróbki drewna. W latach 70. ubiegłego wieku fabryka zatrudniała około 300 osób i produkowała maszyny dla przemysłu drzewnego w Polsce. Jednak 70\% produkcji eksportowano (do Czech, Niemiec, Rosji, Włoch, Hiszpanii oraz Stanów Zjednoczonych). W latach 90. w Chicago był nawet punkt serwisowy, w którym pracowali słupszczanie (Rzeczkowska 2013). W 2000 r. fabryka została sprywatyzowana, jednak dziesięć lat później dopadł ją kryzys, który doprowadził do całkowitej likwidacji zakładu (fot. 1).

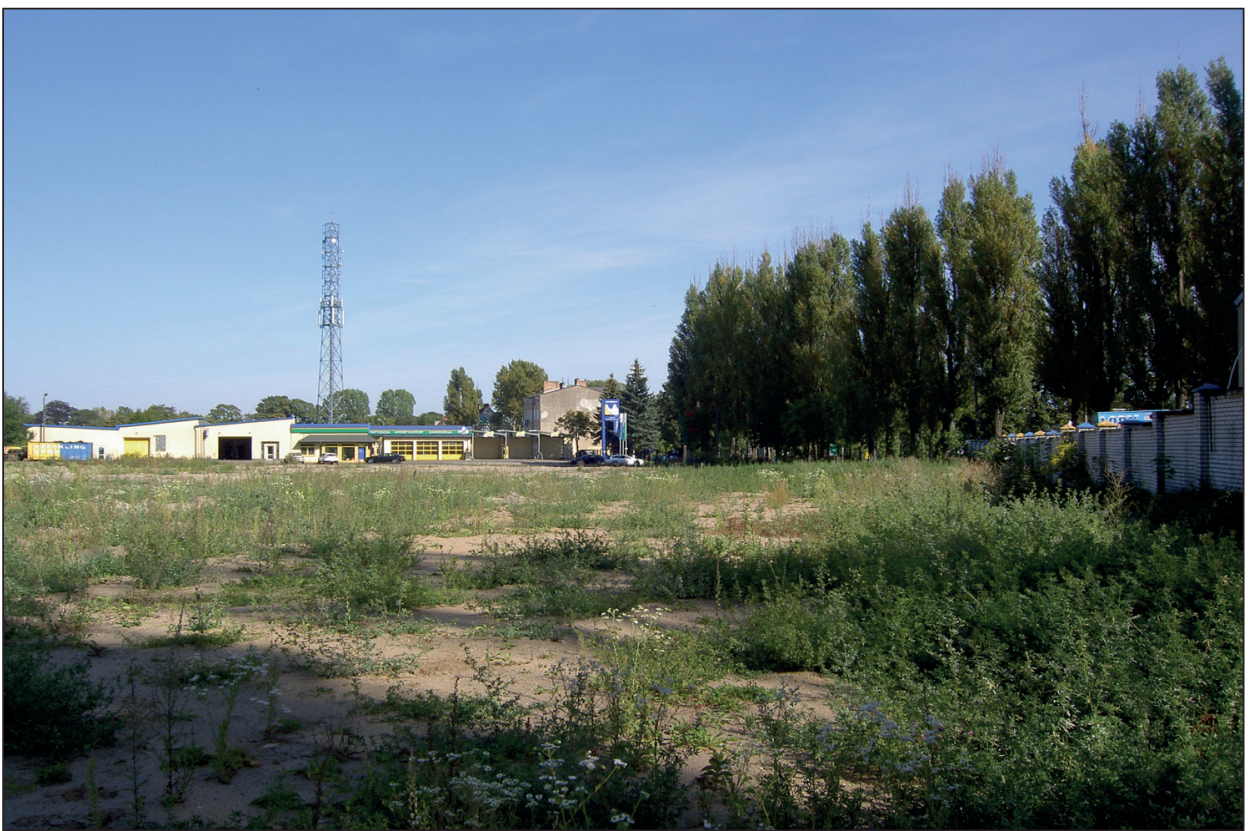

Fot. 1. Teren po Słupskiej Fabryce Obrabiarek SAFO przy ul. Szczecińskiej w 2014 r. (fot. E. Rydz)

W trwającym od 1989 r. okresie transformacji pewnym zmianom uległa także struktura przestrzenna przemysłu Słupska, która z jednej strony jest wynikiem likwidacji zakładów (np. Zakładów Mięsnych, Słupskiej Fabryki Mebli) i wyraźnego ograniczenia zatrudnienia, z drugiej zaś - uruchomienia nowych przedsiębiorstw. Generalnie zachowany został jednak ukształtowany w okresie przyspieszonej industrializacji w latach 70. układ przestrzenny przemysłu Słupska, z jego koncentracją w granicach osiedli Stare Miasto, Nadrzecze i Piastów. Na podkreślenie 
zasługuje również fakt, że $\mathrm{w}$ ciągu ostatnich pięciu lat nastąpiła dalsza koncentracja przemysłu na Osiedlu Nadrzecze, głównie za sprawą uruchomienia nowych przedsiębiorstw, położonych wzdłuż ul. Poznańskiej (drogi wylotowej w kierunki Piły i Poznania) oraz na Osiedlu Bałtyckim, na terenie którego położona jest cześć Słupskiej Specjalnej Strefy Ekonomicznej. Znajdują się tu m.in. nowo uruchomione zakłady produkcji okien PCV „Bajcar”, produkcji szyb samochodowych i drzwi szklanych „NordGlass”, przetwórstwa rybnego „Łosoś”, przemysłu mięsnego „Perelstein", fabryka okien M \& S, firma budowlana „Dombet”, firma transportowa „Paula-Trans".

Przedstawiona analiza wskazuje, że przemysł ośrodka słupskiego w warunkach gospodarki rynkowej przechodzi do fazy dekoncentracji swojej działalności. Wpływają na to wiodące tendencje do ograniczenia działalności produkcyjnej $\mathrm{w}$ dużych przedsiębiorstwach oraz tańsza ich lokalizacja w strefie podmiejskiej (przykładem są m.in. zakłady produkcji obuwia "Nord” w Strzelinku, mebli - Flair Poland w Kobylnicy, a także zakłady mięsne "Grzywaczewski - wędliniarstwo" w Strzelinie oraz rozwój firm związanych z przetwórstwem i konserwowaniem ryb, np. „Morpol Ustka - Poland" w Duninowie).

\section{Przekształcenia terenów przemysłowych. Skala problemu i przykłady przekształceń}

Szybko postępujące przemiany gospodarcze w latach 90. oraz dziedzictwo, często ekstensywnie wykorzystywanych w przeszłości, terenów fabrycznych spowodowały pojawienie się w polskich miastach rozległych niekiedy terenów poprzemysłowych. Skala tego zjawiska, choć szczególnie duża w okręgach i ośrodkach, w których znaczący udział miały branże tradycyjne (Domański 2000), występuje także z różnym nasileniem w średniej wielkości miastach o często zróżnicowanej strukturze gałęziowej przemysłu. Potwierdzeniem tego faktu mogą być badania przeprowadzone w największych do niedawna zakładach przemysłowych na terenie Słupska.

Zasadniczo rozróżnia się trzy rodzaje nieużytkowanych terenów przemysłowych (Gasidło 1998):

- formalnie lub faktycznie porzucone przez właściciela lub dysponenta, tzw. ugory;

- przetrzymywane przez dotychczasowego właściciela $\mathrm{w}$ nadziei ewentualnego ponownego wykorzystania w dotychczasowej funkcji;

- „odłogowe”, w oczekiwaniu na korzystne możliwości zagospodarowania lub sprzedaży w przyszłości. 
Z dotychczas przeprowadzonych badań, poczynionych obserwacji oraz dostępnej literatury (Gasidło 1998; Zioło 2001; Marszał [red.] 2006) wynika, że o ile przez wiele lat omal za naturalne uważano powrót takich gatunków do funkcji przemysłowej, o tyle w późniejszym okresie prawie zawsze regułą stawało się wykorzystanie takich powierzchni do celów nieprodukcyjnych, często usługowych. Interesującym przykładem przekształcenia terenu dużego przedsiębiorstwa w Słupsku stanowi Zakład Urządzeń Okrętowych "Sezamor”, który zajmował grunty rozciągające się od ul. Szczecińskiej do ul. Kołobrzeskiej.

Prowadzona przez przedsiębiorstwo produkcja obejmowała w przeszłości dziewięć typów produktów podstawowych (np. łańcuchy kotwiczne, wyciągi łańcuszkowe, suwnice montażowe, żurawiki łodziowe itp.). Do głównych odbiorców wyrobów należały m.in. znane firmy zagraniczne, np. Wortelboer i Schmitt z Holandii, Centrometr z Anglii, Drekena i Barthels \& Louders z Niemiec oraz Billora z Rosji. W wyniku przeprowadzonej restrukturyzacji majątkowej, przy znacznym spadku zatrudnienia (z 364 osób w 1994 r. do 200 osób w 2002 r.), nastąpiło radykalne zmniejszenie o $2 / 3$ powierzchni terenów przemysłowych dawnego zakładu. Dokonano demontażu budynków fabrycznych, a na części uporządkowanego terenu powstały obiekty handlowe, zajmujące się sprzedażą wyrobów z drewna (firma „Westprofil”) oraz stacja paliw Shell.

Na terenie zakładu powstały także Zakłady Poligraficzne Laminopol, Zakład Produkcji Obuwia „Forma” oraz kolejny salon samochodowy Honda Igmar. Ostateczna likwidacja zakładu nastąpiła w 2005 r. Najwięsza część terenów przemysłowych po byłym Zakładzie Sprzętu Okrętowego "Sezamor" (11,5 ha) została aktualnie zagospodarowana przez Centrum Handlowe "Jantar", którego powstanie stało się ważnym wydarzeniem. O jego znaczeniu stanowi również fakt utworzenia 400 nowych miejsc pracy z myślą o mieszkańcach Słupska i regionu (fot. 2).

Realizowana w dalszym ciągu strategia "odchudzania” przedsiębiorstwa doprowadziła w 1994 r. do sprzedaży majątku zakładowego oraz jego dzierżawy innym podmiotom gospodarczym. Obok przekształceń całych kwartałów lub budynków przemysłowych doszło także do podziału nieruchomości między większą liczbę średnich firm, nabywających lub dzierżawiących obiekty od ich dysponenta. Z badań przeprowadzonych na terenie Fabryki Obuwia „Alka” S.A. wynika, że w dzierżawie znajduje się ok. $43 \%$ gruntów i powierzchni zabudowanych, należących niegdyś do Fabryki Obuwia "Alka” S.A., zaś ok. 30\% powierzchni poprzemysłowej sprzedano m.in. Zakładom Przetwórstwa Ryb „Morpol-Poland" w Duninowie. 


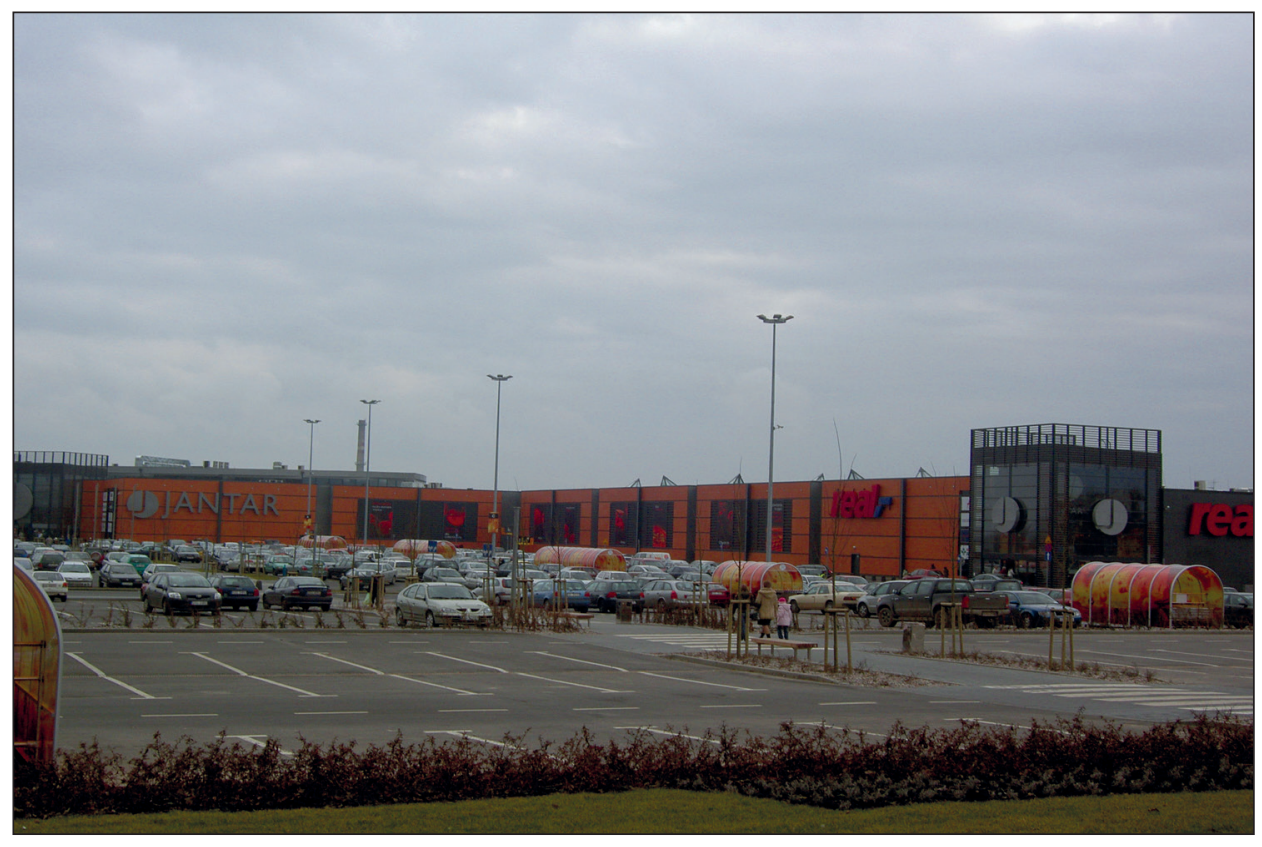

Fot. 2. Teren po byłym Zakładzie Sprzętu Okrętowego „Sezamor” przy ul. Szczecińskiej w 2015 r. (fot. I. Jażewicz)

Na szersze omówienie zasługują procesy przekształceń największego zakładu przemysłowego Słupska, jakim była do 1994 r. Fabryka Obuwia "Alka" S.A. (1250 osób zatrudnionych). Istotną rolę w funkcjonowaniu przedsiębiorstwa odegrało jego wejście do grupy kapitałowej „POT” BUT-S S.A. z Łodzi, będącej potentatem w produkcji obuwia damskiego, męskiego i młodzieżowego. W ramach przekształceń, w które zaangażowały się władze miasta, opracowano m.in. kilka koncepcji zagospodarowania kwartałów przemysłowych. Miasto nabyło również niektóre nieruchomości, np. Szkołę Przyzakładową (dawny Zespół Szkół Obuwniczych), a także przedszkole.

Wyraźna zmiana użytkowania terenów przemysłowych nastąpiła również w Fabryce Maszyn Rolniczych „Famarol” S.A., położonej między ulicami Przemysłową a Poznańską na Osiedlu Nadrzecze. Restrukturyzację majątku trwałego zakładu, który rozpoczął działalność już w 1947 r., zapoczątkowano w 1994 r. Na pierwszym etapie obejmowała sprzedaż krajalni i łłoczni, prototypowni i składu złomu. W kolejnych latach wydzierżawiono magazyn farb oraz $1 / 3$ powierzchni biurowca (m.in. Zespołowi Szkół Niepublicznych) oraz produkcyjny magazyn operacyjny. Kolejnym znaczącym etapem restrukturyzacji zakładu było przekształcenie się narzędziowni w spółkę z kapitałem obcym. 
$\mathrm{W}$ ramach postępującej restrukturyzacji majątku trwałego zakładu nastąpiło zmniejszenie powierzchni przemysłowej Fabryki Maszyn Rolniczych „Famarol” S.A. o ponad 43\%, w tym powierzchni pod dachem o $40 \%$ (z $44621 \mathrm{~m} 2$ do $26621 \mathrm{~m} 2$ ). W części obiektów sprzedanych i wydzierżawionych powstały hurtownie materiałów budowlanych, zakłady naprawcze i rzemieślnicze, a także hurtownia materiałów metalowych "Centrostal".

Przykładem nieudanej restrukturyzacji zakładu jest upadłość i likwidacja Słupskich Fabryk Mebli - zakładu, który bardzo mocno wtopił się w krajobraz przemysłowy ośrodka słupskiego. Procesy restrukturyzacyjne, polegające na wykorzystaniu inwestorów zagranicznych i kapitału krajowego doprowadziły w efekcie do całkowitego bankructwa zakładu, który jeszcze w połowie lat 90. należał do dość dobrze prosperujących. $\mathrm{Na}$ części gruntów przemysłowych zlokalizowano obiekty handlowe (np. market „Lidl” przy ul. Jaracza i Lutosławskiego) czy też sklep meblowy „Black-Red-White” przy ul. Kaszubskiej. Zdecydowanie największa powierzchnia po Zakładach Meblowych Słupskiej Fabryki Mebli, położona między ulicami Grottgera, Szczecińską i Malczewskiego, od blisko 20 lat jest niewykorzystana i jest klasycznym „odłogiem” poprzemysłowym (fot. 3).

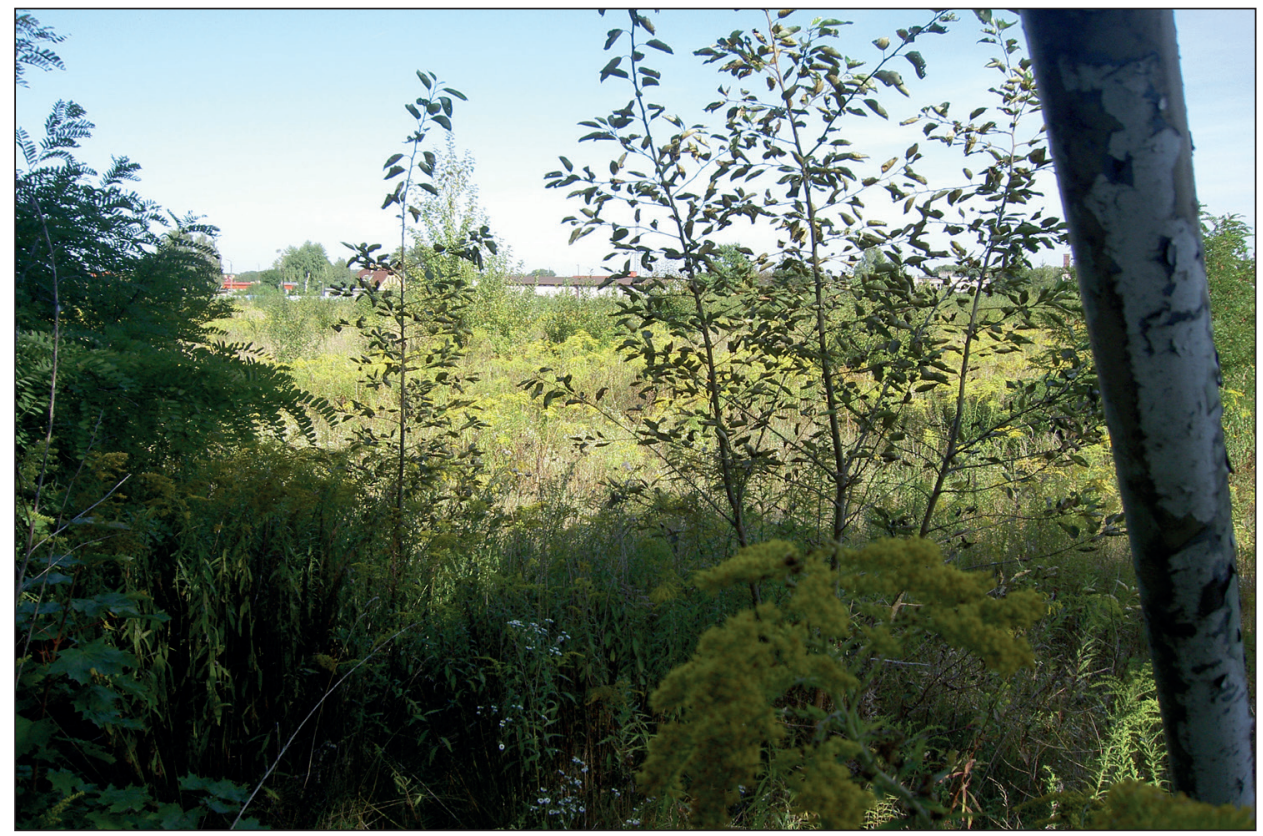

Fot. 3. Teren po Zakładach Meblowych Słupskiej Fabryki Mebli przy ul. Grottgera i Malczewskiego w 2015 r. (fot. E. Rydz) 
Przeprowadzone badania wskazują, że radykalna zmiana użytkowania terenów przemysłowych nastąpiła w centralnej części Słupska na osiedlach Stare Miasto i Piastów oraz na terenach przemysłowych, położonych przy drogach wylotowych z miasta (np. przy ulicach Poznańskiej i Szczecińskiej). Natomiast przy ul. Bałtyckiej (Osiedle Bałtyckie), na gruntach po Okręgowej Spółdzielni Mleczarskiej, zlokalizowane są dwie największe hurtownie materiałów budowlanych i wyposażenia wnętrz („Fimal” i „Rebis”). Generalnie najczęstszym kierunkiem współczesnych przekształceń terenów przemysłowych jest ich wykorzystanie na działalność handlowa, usługowa, przemysłowa, a niekiedy edukacyjną.

Proces przekształceń terenów przemysłowych Słupska wyraźnie wskazuje, że tempo i charakter zachodzących zmian zależą od położenia terenu $\mathrm{w}$ strukturze przestrzennej miasta. Najbardziej widoczne przekształcenia w użytkowaniu terenów przemysłowych wystąpiły na działkach położonych przy arteriach wylotowych miasta - tam praktycznie nastąpiła niemal całkowita zmiana charakteru ich wykorzystania. Ukształtowały się w ten sposób nowe centra handlowo-usługowe, składające się z wielkopowierzchniowych obiektów handlowych, np. przy ul. Szczecińskiej.

Ważną cechą, różnicującą zachodzące przekształcenia, jest trwałość zagospodarowania (Domański 2000). Z badań prowadzonych na terenie Słupska wynika, że obok przekształceń o charakterze długofalowym, w wyniku których powstają nowe przedsiębiorstwa, budynki biurowe, banki itd., istnieje także cała gama względnie nietrwałego doraźnego zagospodarowania (np. dzierżawa pod drobną działalność handlowo-usługową i magazynową przy ulicach Pomorskiej, Przemysłowej i Poznańskiej).

\section{Uwagi końcowe}

Zapoczątkowana pod koniec 1989 r. restrukturyzacja przemysłu w ośrodku słupskim spowodowała dość istotne zmiany w strukturze wielkościowej zakładów. Preferowany na przełomie lat 60 . wzrost stopnia koncentracji zatrudnienia $\mathrm{w}$ dużych zakładach nie sprostał w pełni wymogom gospodarki rynkowej po 1989 r. Nastąpił ogólny spadek liczby zatrudnionych w przemyśle Słupska oraz zmienił się stopień koncentracji pracujących w dużych zakładach.

Z przeprowadzonych badań wynika, że w okresie ostatnich 25 lat zmianom uległa struktura przestrzenna przemysłu Słupska, która jest, z jednej strony, wynikiem likwidacji dużych zakładów, z drugiej zaś - świadczy o uruchomieniu nowych mniejszych przedsiębiorstw. Na podkreślenie 
zasługuje fakt, że w ciągu ostatnich dziesięciu lat nastąpiła dalsza koncentracja przemysłu na Osiedlu Nadrzecze, głównie dzięki uruchomieniu nowych przedsiębiorstw, położonych wzdłuż ul. Poznańskiej (drogi wylotowej w kierunku Piły i Poznania) oraz na Osiedlu Bałtyckim, na terenie którego położona jest część Słupskiej Strefy Ekonomicznej.

Wyniki badań wskazuja że przemysł ośrodka słupskiego w warunkach gospodarki rynkowej przechodzi do fazy dekoncentracji swojej działalności. Wpływają na to ograniczenia działalności produkcyjnej $\mathrm{w}$ dużych zakładach oraz powstanie nowych zakładów, np. obuwniczych.

Przedstawiony proces przekształceń użytkowania terenów przemysłowych Słupska wyraźnie wskazuje, że tempo i charakter zmian zależą od położenia terenu $\mathrm{w}$ strukturze przestrzennej miasta. Najliczniejsze przekształcenia użytkowania terenów przemysłowych nastąpiły, z jednej strony, w tkance miejskiej Słupska, gdzie praktycznie nastąpiła prawie całkowita zmiana charakteru wykorzystania tych terenów, z drugiej zaś - w obrębie dużych do niedawna przedsiębiorstw. Na podkreślenie zasługuje nowe zagospodarowanie przemysłowe terenów położonych na obrzeżach miasta, przy arteriach wylotowych w kierunku Szczecina, Piły i Poznania oraz Ustki. Odrębnym problemem są trudności zagospodarowania byłych terenów poprzemysłowych z istniejącymi jeszcze

234 obiektami wpisanymi do rejestru zabytków (np. Browar Słupski). Działania takie prowadzą do daleko posuniętej dekapitalizacji zabudowy, a także infrastruktury nieużytkowanego terenu.

\section{Literatura}

Domański B. (2000), Tereny przemystowe w miastach polskich - kierunki i bariery przeksztatceń, [w:] I. Jażdżewska (red.), Miasto postsocjalistyczne-organizacja przestrzeni miejskiej i jej przemiany, XIII Konwersatorium Widzy o Mieście, Uniwersytet Łódzki, Łódź, s. 139-143.

Gasidło K. (1998), Problemy przekształceń terenów przemysłowych, „Zeszyty Naukowe Politechniki Śląskiej", Architektura, nr 37, s. 54-72.

Lindmajer J., Machura T., Spors J., Wachowiak B. [red.] (1986), Dzieje Stupska, Polskie Towarzystwo Historyczne, Oddział w Słupsku, Słupsk.

Liszewski S. (1997), Przemiany funkcjonalno-przestrzenne terenów przemysłowych Łodzi, [w:] P. Korcelli (red.), Aglomeracje miejskie w procesie transformacji, Instytut Geografii i Przestrzennego Zagospodarowania PAN, z. 46, s. 23-38.

Machura T. (1975), Rozwój przemystu w Stupsku w latach 1945-1974, „Koszalińskie Studia i Materiały", nr 3, Koszaliński Ośrodek Naukowo-Badawczy, Koszalin, s. 20-33.

Marszał T. [red.] (2006), Wybrane zagadnienia zagospodarowania przestrzennego, Wyd. Uniwersytetu Łódzkiego, Łódź.

Rajman J. (2001), Zmienna rola przemysłu jako czynnika miastotwórczego, [w:] J. Rajman (red.), Polska-Europa. Gospodarka, przemyst, Wyd. Naukowe Akademii Pedagogicznej w Krakowie, Kraków, s. 109-124. 
Rydz E. (1990), Funkcje Koszalina i Stupska w regionalnej sieci osadniczej, Wyższa Szkoła Pedagogiczna, Słupsk.

Rydz E. (1999), Zmiany w strukturze użytkowania ziemi na przykładzie Stupska i Szczecinka, [w:] J. Kaczmarek (red.), Przestrzeń miejska, jej organizacja i przemiany, XII Konwersatorium Wiedzy o Mieście, Katedra Geografii Miast i Turyzmu Uniwersytetu Łódzkiego, Łódzkie Towarzystwo Naukowe, Łódź, s. 9-19.

Rydz E. (2009), Przemiany przestrzeni miejskiej Stupska w okresie urynkowienia gospodarki, [w:] I. Jażdżewska, Sfera podmiejska i mate miasta w okresie transformacji, XXII Konwersatorium Wiedzy o Mieście, Instytut Geografii Miast i turyzmu Uniwersytetu Łódzkiego, Łódź, s. 145-158.

Rydz E., Jażewicz I. (1997), Procesy transformacji słupskiego ośrodka przemysłowego w latach 1990-1995, [w:] Z. Zioło (red.), Problemy transformacji struktur przemysłowych w procesie przechodzenia do gospodarki rynkowej, Komisja Geografii Przemysłu PTG, WarszawaKraków, s. 47-59.

Rydz E., Szymańska W. (2002), Efekty restrukturyzacji stupskiego ośrodka przemysłowego w okresie wdrażania gospodarki rynkowej na wybranych przykładach, [w:] Z. Zioło, T. Rachwał (red.), Efekty restrukturyzacji polskiej przestrzeni przemystowej, „Prace Komisji Geografii Przemysłu PTG", nr 9, s. 40-51.

Rydz E., Zaleski J. (1992), Rola i funkcje Stupska na tle sieci osadniczej Środkowego Wybrzeża, Wyższa Szkoła Pedagogiczna, Słupsk.

Rzeczkowska B. (2013), Safo kończy w ogniu, „Głos Pomorza”, 12-13 lipca, nr 162, s. 1.

Zioło Z. (2001), Struktura branżowa i koncentracja przestrzenna wiodacych światowych firm przemystowych, [w:] Z. Zioło (red.), Problemy przemian struktur przemystowych w procesie wdrażania reguł gospodarki rynkowej, „Prace Komisji Geografii Przemysłu PTG”, nr 3.

Eugeniusz Rydz, prof. dr hab., Wydział Ekonomiczny, Politechnika Koszalińska 